\title{
Killing it Softly: Girdling as an Efficient Eco-friendly Method to Locally Remove Invasive Acer negundo ${ }^{\circ}$ a
}

\author{
Nastasia R. Merceron, Laurent J. Lamarque, Sylvain Delzon and Annabel J. Porté
}

\begin{abstract}
Acer negundo (boxelder maple) is a North American native tree species that currently invades riparian and disturbed areas in Europe, affecting both bank stability and ecosystem biodiversity. As a response to managers' requests, we aimed at finding an eco-friendly method which would locally remove this species and help habitat restoration. Four control methods were tested on $A$. negundo adults and saplings from stands located in three experimental sites along different watercourses in Southwestern France: girdling, low cutting, high cutting, and cutting followed by the application of juglone (a natural allelopathic substance from walnut tree leaves). Mortality and resprout production on the treated $A$. negundo individuals were assessed during two years following the application of the control methods. Girdling was the most efficient method as it significantly induced higher mortality rates compared to the others (65 vs $15 \%$ of dead $A$. negundo two years after treatment administration). When healing emerged on trunks, yearly repeated girdling was required to reach full success. None of the control methods significantly reduced resprout production; not even the application of juglone. Girdling is the most recommended method to kill and remove $A$. negundo at a local scale in invaded natural habitats. Considering that $A$. negundo benefits from increases in light availability to outcompete native species, we further recommend removing seedlings from understories when applying girdling on adult and sapling individuals in order to optimize restoration conditions in natural stands and improve native species re-establishment.
\end{abstract}

Keywords: control methods, habitat restoration, management practices, tree invasion

\section{\$) Restoration Recap i(}

- Girdling is an efficient eco-friendly control method to locally remove individual adults and saplings of Acer negundo, a resprouting tree invading European riparian forests and wetlands.

- Repeated girdling is necessary over two or three years to kill $A$. negundo individuals when stem healing is observed and to remove resprouts from the stems during spring time after leaf development.
- Timing of treatment application should be synchronized with tree cuttings or tree falls to impede release of $A$. negundo understory trees in light gap conditions.

- Seedlings should also be removed from the managing sites during at least two years after girdling of adult trees and saplings in order to control regeneration and allow native tree species to re-establishment. nvasive plants significantly decrease native species diversity and modify ecosystem processes within invaded

Color version of this article is available through online subscription at: http://er.uwpress.org

D This open access article is distributed under the terms of the CC-BYNC-ND license (http://creativecommons.org/licenses/by-nc-nd/3.0) and is freely available online at: http://er.uwpress.org

Ecological Restoration Vol. 34, No. 4, 2016

ISSN 1522-4740 E-ISSN 1543-4079

(C2016 by the Board of Regents of the University of Wisconsin System. communities (Vilà et al. 2011) resulting in large investments to manage and restore these ecosystems (Pimentel et al. 2005). Riparian ecosystems are highly subjected to invasions given that (i) rivers are efficient dispersal corridors for propagules over long distances (Säumel and Kowarik 2010), and (ii) frequent disturbances increase nutrient and light availability (Hood and Naiman 2000). Because they act as critical buffer zones along water courses (Correll 1996), traditional practices of invasive plant removal, inducing soil disturbance or chemical pollution, should be avoided. In France, chemical pesticides are forbidden in wetlands 
and forests (Journal Officiel de la République Française 2006). One challenge is therefore to develop efficient and eco-friendly methods to constrain plant invasions and restore invaded habitats.

Chemical, biological, and mechanical methods largely used by managers to control invasive herbaceous plants (Holt 2009) have also been tested on invasive woody species (van Wilgen et al. 2001). To date, broad-spectrum herbicide applications, i.e., Trycoplyr (Patch et al. 1998, Burch and Zedaker 2003) and Glyphosate (Walter et al. 2004, Itou et al. 2015), are the most efficient methods to kill invasive resprouting tree species. However, these practices can have substantial ecological consequences on non-target species if sprayed or by contaminating soil and water. Infections by pathogen fungi such as Chondrostereum purpureum (De Jong 2000, Becker et al. 2005) and Fusarieum spp. (Ding et al. 2006) were also used with success but no homologation of these pathogens exist in Europe. Moreover, these generalist pathogens present a risk regarding native species and testing introduced ones would risk introducing a new virulent invasive species (Simberloff and Stiling 1996). In weed management, allelopathic compounds have also been used (Macías et al. 2007) but to our knowledge, allelopathic substances produced by native species were never tested to control invasive plants. Finally, mechanical methods (mowing, mulching, cutting, burning, uprooting, or girdling) are also largely used to eliminate invasive trees (Sabo 2000, Meloche and Murphy 2006, Loh and Daehler 2007, Tanaka et al. 2010). Although it is often time consuming, methods such as girdling or cutting can be applied on targeted individuals thus avoiding environmental impacts. Girdling is a common practice in forestry (MacKinney and Korstian 1932, Noel 1970) and is advised to locally eliminate invasive woody species in natural areas (Loh and Daehler 2007). However, partial girdling is a poorly efficient method to kill the resprouting invasive species Robinia pseudoacacia (black locust) and Ailanthus altissima (tree of heaven) (Kowarik and Säumel 2007, Cierjacks et al. 2013), therefore such methods has to be evaluated on more invasive tree species.

Native to North America, A. negundo (boxelder maple) is an alien species in Europe that has heavily invaded wetlands and riparian forests. The species' high resprouting ability leads to unsuccessful control by natural area managers using repeated cutting. Here, we aim to test ecologically-friendly methods to kill $A$. negundo to offer tools to managers involved in restoration. Cutting was used to mimic their current practices and we hypothesized that the use of an allelopathic substance (juglone) or stem girdling would prove more efficient due to their impacts on plant physiology. Efficiency was assessed during two years following treatment application and management recommendations are proposed.

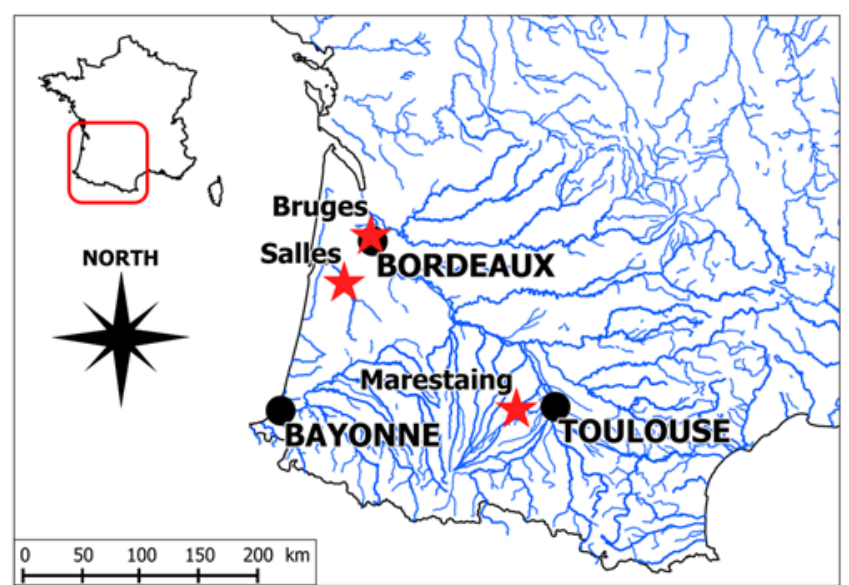

Figure 1. Map of the study area, including experimental sites (red stars), main cities (black dots), and the river network which favors the proliferation of Acer negundo in Southwestern France. The blank base map was provided free of charge and use by Daniel Dalet (Académie Aix-Marseille, www.pedagogie.ac-aixmarseille.fr/jcms/c_51055/fr/cartotheque-compacte).

\section{Methods}

\section{Target Species}

Acer negundo is a medium size, dioecious tree native to North America and intentionally introduced in Europe during the seventeenth century (Kowarik 2003), for horticulture and landscaping purposes. It has escaped from urban areas and colonized river banks and wetlands, becoming invasive throughout Southern and Eastern Europe and considered as one of the most invasive plant species in these habitats (DAISIE 2010). A female individual can produce high quantities of seeds (Schopmeyer 1974), about 100,000-500,000 samaras, dispersed by wind and water (Medrzycki 2011). Moreover, individuals have the ability to produce new vegetative sprouts following human cuttings or natural disturbances. Locally, this species may form monospecific stands (Lamarque et al. 2012), reducing both native species richness and abundance by decreasing light availability (Saccone et al. 2010, BottollierCurtet et al. 2012). In France, A. negundo invasion leads to replacement of economically important trees such as Salix alba (white willow) (Bottollier-Curtet et al. 2012) and Populus spp., to river bank collapses and reduces bird nesting (L. Degrave, Parc Naturel Régional des Landes de Gascogne and S. Buyle, Réserve Naturelle des Marais de Bruges, pers. comm.).

\section{Experimental Design}

Three riparian stands, Bruges, Marestaing, and Salles, were selected in Southwestern France because of their high densities of $A$. negundo (Figure 1). Bruges is a swampy forest which dominated by even-sized A. negundo and large Fraxinus excelsior (European ash) trees. Marestaing, 
Table 1. Stands characteristics of three invaded forest stands in southwestern France. For each forest stand, density (tree/ha), relative density (\%), mean diameter at breast height (dbh, $\mathrm{cm} \pm \mathrm{SD})$ and basal area $\left(\mathrm{m}^{2} / \mathrm{ha}\right)$ of adult trees are presented per species and for the whole plot (All). The geographic coordinates (degree, minutes and seconds) of each site are indicated below the stand name. The asterisks denote the species which were represented by only one tree in the experimental plots, thus explaining the absence of SD values.

\begin{tabular}{|c|c|c|c|c|c|}
\hline Forest stand & Species & $\begin{array}{l}\text { Density } \\
\text { (tree/ha) }\end{array}$ & $\begin{array}{c}\text { Relative density } \\
(\%)\end{array}$ & $\begin{array}{l}\text { Mean dbh } \\
(\mathrm{cm} \pm \mathrm{SD})\end{array}$ & $\begin{array}{c}\text { Mean basal area } \\
\left(\mathrm{m}^{2} / \mathrm{ha}\right)\end{array}$ \\
\hline Bruges & Acer negundo & 1,772 & 68.4 & $8.0 \pm 6.8$ & 15.2 \\
\hline$\left(44^{\circ} 54^{\prime} 27.11^{\prime \prime} \mathrm{N}\right.$ & Alnus glutinosa & 33 & 1.3 & $10.9 \pm 13.6$ & 0.7 \\
\hline \multirow[t]{5}{*}{$\left.0^{\circ} 36^{\prime} 18.66^{\prime \prime} \mathrm{W}\right)$} & Fraxinus excelsior & 417 & 16.1 & $17.4 \pm 9.7$ & 12.9 \\
\hline & Platanus sp.* & 8 & 0.3 & 20.4 & 0.3 \\
\hline & Quercus robur & 73 & 2.8 & $11.3 \pm 15.3$ & 1.9 \\
\hline & Ulmus procera & 286 & 11.1 & $3.0 \pm 2.8$ & 0.4 \\
\hline & All & 2,589 & 100 & - & 31.4 \\
\hline \multirow{7}{*}{$\begin{array}{l}\text { Marestaing } \\
\left(43^{\circ} 34^{\prime} 31.56^{\prime \prime} \mathrm{N},\right. \\
\left.1^{\circ} 01^{\prime} 39.68^{\prime \prime} \mathrm{E}\right)\end{array}$} & Acer negundo & 1,655 & 72.0 & $10.2 \pm 6.8$ & 19.7 \\
\hline & Alnus glutinosa & 29 & 1.3 & $10.6 \pm 2.6$ & 0.3 \\
\hline & Fraxinus excelsior & 97 & 4.3 & $10.6 \pm 12.1$ & 1.9 \\
\hline & Populus alba* & 10 & 0.4 & 43.2 & 1.4 \\
\hline & Salix alba* & 10 & 0.4 & 52.0 & 2.1 \\
\hline & Ulmus procera & 497 & 21.6 & $5.0 \pm 4.5$ & 1.7 \\
\hline & All & 2,298 & 100 & - & 27.1 \\
\hline \multirow{8}{*}{$\begin{array}{l}\text { Salles } \\
\left(44^{\circ} 32^{\prime} 54.13^{\prime \prime} \mathrm{N},\right. \\
\left.0^{\circ} 52^{\prime} 18.05^{\prime \prime} \mathrm{W}\right)\end{array}$} & Acer negundo & 4,788 & 90.6 & $4.9 \pm 3.6$ & 13.7 \\
\hline & Alnus glutinosa & 57 & 1.1 & $6.9 \pm 3.2$ & 0.2 \\
\hline & Carpinus betulus & 19 & 0.4 & $8.5 \pm 0.3$ & 0.1 \\
\hline & Populus nigra* & 10 & 0.2 & 2.7 & $<0.01$ \\
\hline & Populus sp. & 372 & 7.0 & $19.4 \pm 8.7$ & 13.2 \\
\hline & Quercus robur* & 10 & 0.2 & 5.6 & 0.02 \\
\hline & Ulmus procera & 29 & 0.5 & $7.8 \pm 3.6$ & 0.2 \\
\hline & All & 5,284 & 100 & - & 27.4 \\
\hline
\end{tabular}

located along the Save river, is a riparian forest mainly composed of small Ulmus minor (field elm) and numerous medium-sized A. negundo individuals. Salles, located along the L'Eyre River, is a riparian Populus sp. plantation largely invaded by abundant and small $A$. negundo trees (Table 1).

Each stand was divided into four plots, and each of the four control methods were randomly assigned to one plot (average area $220 \pm 21 \mathrm{~m}^{2}$ ). Control methods were specifically applied to $A$. negundo saplings $(0.5 \mathrm{~m}<$ height $<3 \mathrm{~m}$ ) and adult trees (height $>3 \mathrm{~m}$ ) (Table 2) in May-June 2009 , after sap rise and when leaves were fully developed. A unique code indicating the number of the tree and the control method applied was grafted to the base of the tree to follow successive analyses. The native species remained untouched. Saplings and adult trees were counted to assess tree density per species and diameter at breast height (dbh, $\mathrm{cm})$ was measured using a dendrometric tape $( \pm 0.1 \mathrm{~cm})$.
All A. negundo seedlings (height $<0.5 \mathrm{~m}$ ) were counted and removed out of the plots as were cutting residues. Four treatments were tested: 1) stem girdling, 2) high stem cutting, 3) low stem cutting, and 4) juglone application on cut trees. Stem girdling (Figure 2A, B) was performed at $1.30 \mathrm{~m}$ from the ground, using an axe or a machete to remove the bark, phloem, and cambium over a $30 \mathrm{~cm}$ long segment around the whole circumference. This approach allowed undamaged xylem tissues to keep supplying water and nutrients (raw sap) to the crown while removing phloem tissues prevented the distribution of sugars (elaborated sap) towards the stump and the root system. The purpose was to exhaust the tree to death as below-ground organs would die first and to avoid recurring resprouting. High stem cutting (Figure 2C) and low stem cutting (Figure 2F) were applied using a chainsaw at $1.30 \mathrm{~m}$ and $20 \mathrm{~cm}$ from the ground, respectively. These two methods aimed at

Table 2. Number of Acer negundo saplings and adults treated with each of the four control methods (stem girdling, high stem cutting, low stem cutting, juglone application) in each forest stand (Bruges, Marestaing, Salles).

\begin{tabular}{lccccccccc}
\hline & \multicolumn{2}{c}{ Girdling } & \multicolumn{2}{c}{ Low cutting } & \multicolumn{2}{c}{ High cutting } & \multicolumn{2}{c}{ Cutting + Juglone } \\
\cline { 2 - 8 } Forest stand & Saplings & Adults & Saplings & Adults & Saplings & Adults & Saplings & Adults & Total \\
\hline Bruges & 0 & 14 & 6 & 41 & 3 & 53 & 5 & 65 & 187 \\
Marestaing & 0 & 46 & 0 & 38 & 3 & 20 & 0 & 41 & 148 \\
Salles & 2 & 60 & 16 & 131 & 10 & 129 & 9 & 124 & 481 \\
\hline
\end{tabular}



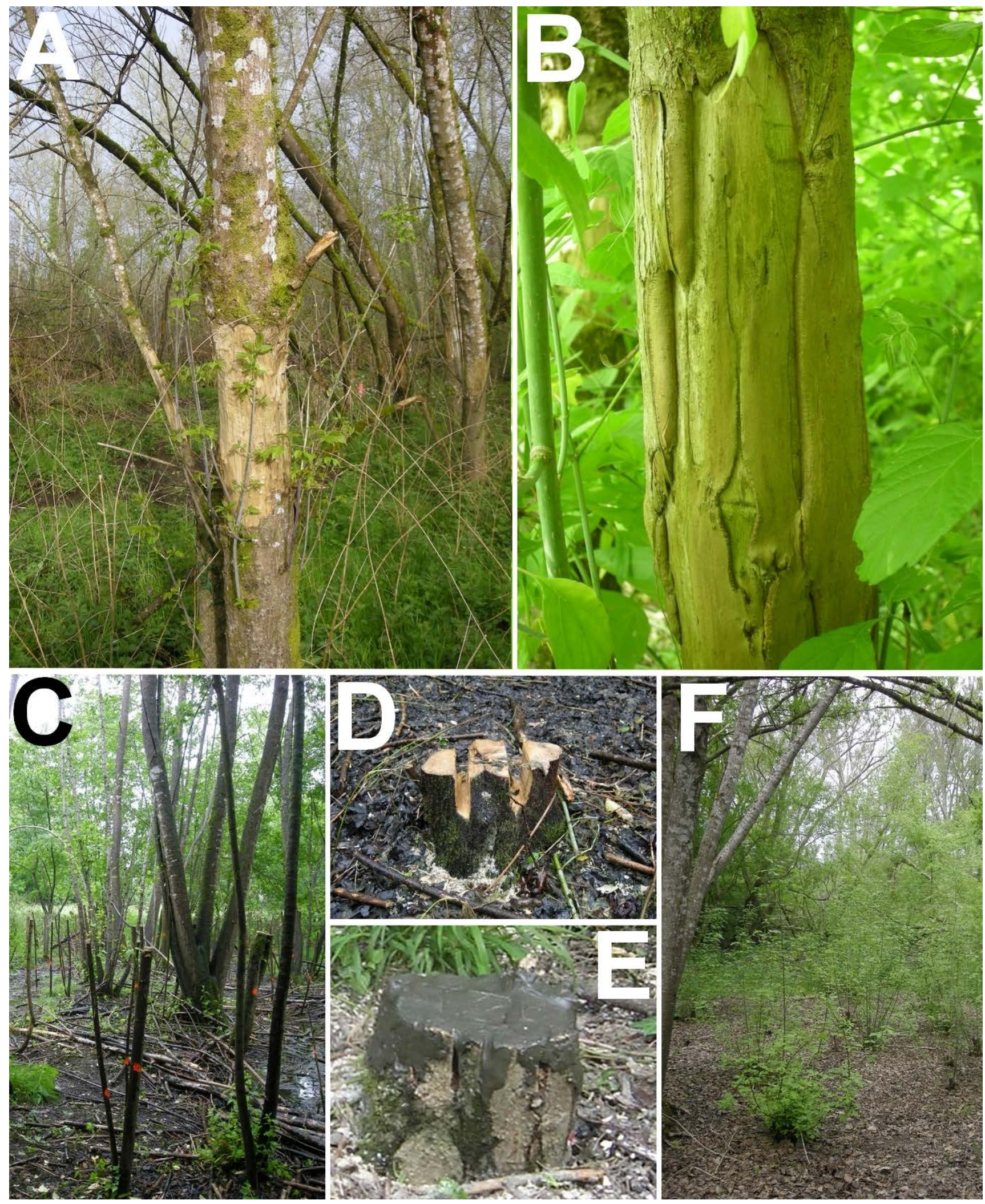

Figure 2. Illustration of the four control methods tested to kill individuals of Acer negundo: A) stem girdling presenting some small resprouts one year after treatment application (Salles, March 2010); B) close view of the girdled zone presenting stem healing (Marestaing, May 2010); C) general view of a plot after first treatment with the high stem cutting method (Salles, May 2009); D) close view of a stem cut which received application of the juglonebased mixture (Salles, May 2009) and E) once covered with healing balm to prevent leaks (Salles, May 2009); and F) low cuttings mimicking managers' current practices with numerous resprouts one year after first application of the treatment (Salles, April 2010). Photo Credit: A.J. Porté 
mimicking common tree removal management practices in forestry. Juglone was applied as a mixture inside the stump after cutting at the tree base (Figure 2D, E). The Juglone mixture was made of crushed walnut leaves (3000 g, Côme and Verbena SARL, Aubenas, France), a binding substance (500 g, acacia gum powder, Fisher Scientific G/1050/53) and water (91). A healing balm (Lac Balsam, Scotts France SAS, Medan SA Eysines, France) was applied on treated stumps to avoid any leakage. Walnut tree (Juglans sp.) leaves naturally contain significant amounts of juglone, an active allelopathic substance with herbicide properties (Rietveld 1983). Because juglone acts on plant growth by reducing photosynthesis, respiration, and blocking cell development (Neave and Dawson 1989, Jose and Gillespie 1998, Ercisli et al. 2005), we expect it to limit resprouting. Walnut leaves were preferred for juglone extract for cost reasons that would have prevented the actual use of the method by managers.

\section{Evaluating Method Efficiency}

Control method efficiency was evaluated on treated trees, encompassing both adults and saplings, in May during two years following first treatment application $(\mathrm{Y}+1-2010$, $\mathrm{Y}+2$ - 2011). Mortality of $A$. negundo was assessed by a visual survey of the absence of leaves in the crown and resprouts on the trunk. The total number of resprouts per tree was counted and the diameters $(\mathrm{mm})$ of the five biggest resprouts per tree were measured using an electronic caliper. The mortality rate per treatment (\%) was calculated as the ratio of the number of dead trees to the total number of treated trees. A final assessment of mortality was performed during a third year on the Salles and Marestaing sites on the cut and girdled plots only $(\mathrm{Y}+3-2012)$. All resprouts were cut and removed from the plot. When healing had occurred on the stem of a girdled trees (Figure 2B), girdling was applied again.

\section{Statistical Analyses}

Analyses were conducted separately for each year of the experiment in order to provide information on the efficiency of the treatment at different time steps. Mortality of $A$. negundo individuals was analyzed using a generalized linear mixed model with a binary distribution and logit link function (procedure GLIMMIX in SAS, v. 9.4, SAS Institute, Cary, NC). Number of resprouts and mean diameter of the five biggest resprouts were analyzed using a linear mixed model (procedure MIXED in SAS, v. 9.4, SAS Institute, Cary, NC). The method was declared as a fixed effect, site and site $\mathrm{x}$ method interaction as random effects. The site effect was removed from the analysis when it did not present enough variation to get a proper estimate of the variance (Kiernan et al. 2012). Tree diameter was used to test for a possible covariance effect.

\section{Results}

One year after treatment application, there was no significant effect of the treatments on the mortality of $A$. negundo $(Y+1$, Table 3$)$. However, mortality increased in all treatments after two years. There was no significant effect of tree diameter on tree mortality for any tested method (data not shown), so all saplings and adults were pooled together for analyses. The second year after the experimental setting, there was a significant effect of the treatment methods $(\mathrm{Y}+2$, Table 3$)$ : girdling was the most efficient method (Figure 3 ) with a $65 \%$ average mortality rate. A large variability among sites was observed with $32.6 \%$ of mortality in Marestaing and $100 \%$ in Bruges. Three years after the first treatment application (Y $+3-2012)$, mortality rates after girdling reached $78 \%$ and $75 \%$, in Marestaing and Salles, respectively. High cutting was the least efficient treatment across all sites; it even failed to kill a single tree in Bruges (Figure 3). Overall, juglone application was no more efficient than the high and low cutting methods.

Table 3. Results from mixed model analyses testing for the response of Acer negundo individuals in terms of mortality, number of resprouts, and mean diameter of the five biggest resprouts per individual. Analyses were performed independently for each monitoring year that followed method application $(Y+1, Y+2)$. Method was treated as a fixed effect ( $F$ test values for fixed effects). Site and site $\times$ method interaction were treated as random effects (ChiSq in proc glimmix, $Z$ in proc mixed), but site was removed from the analysis when presenting not enough variation to get a proper estimate of the variance. $\mathbf{d f}=$ degrees of freedom. Asterisks $\left(^{*}\right)$ indicate statistically significant values $(p<0.05)$.

\begin{tabular}{|c|c|c|c|c|c|c|c|c|}
\hline & \multirow[b]{2}{*}{ Year } & \multirow[b]{2}{*}{ df } & \multicolumn{2}{|c|}{ Method } & \multicolumn{2}{|c|}{ Site } & \multicolumn{2}{|c|}{ Site $x$ method } \\
\hline & & & $\mathbf{F}$ & $p$ & $x^{2} / Z$ & $p$ & $x^{2} / Z$ & $p$ \\
\hline \multirow[t]{2}{*}{ Mortality } & $Y+1$ & 3 & 1.66 & 0.27 & 0.7 & 0.20 & 1.7 & 0.10 \\
\hline & $Y+2$ & 3 & 4.09 & $0.04^{*}$ & - & - & 29.68 & $<0.0001^{*}$ \\
\hline \multirow[t]{2}{*}{ Number of resprouts } & $Y+1$ & 3 & 7.15 & $0.02^{*}$ & 0.88 & 0.19 & 1.47 & 0.07 \\
\hline & $Y+2$ & 3 & 3.66 & 0.10 & 0.71 & 0.24 & 1.38 & 0.09 \\
\hline \multirow[t]{2}{*}{ Mean diameter $(\mathrm{mm})$} & $Y+1$ & 3 & 6.51 & $0.02^{*}$ & 0.84 & 0.20 & 1.65 & 0.05 \\
\hline & $Y+2$ & 3 & 5.30 & 0.05 & 0.60 & 0.27 & 1.40 & 0.08 \\
\hline
\end{tabular}



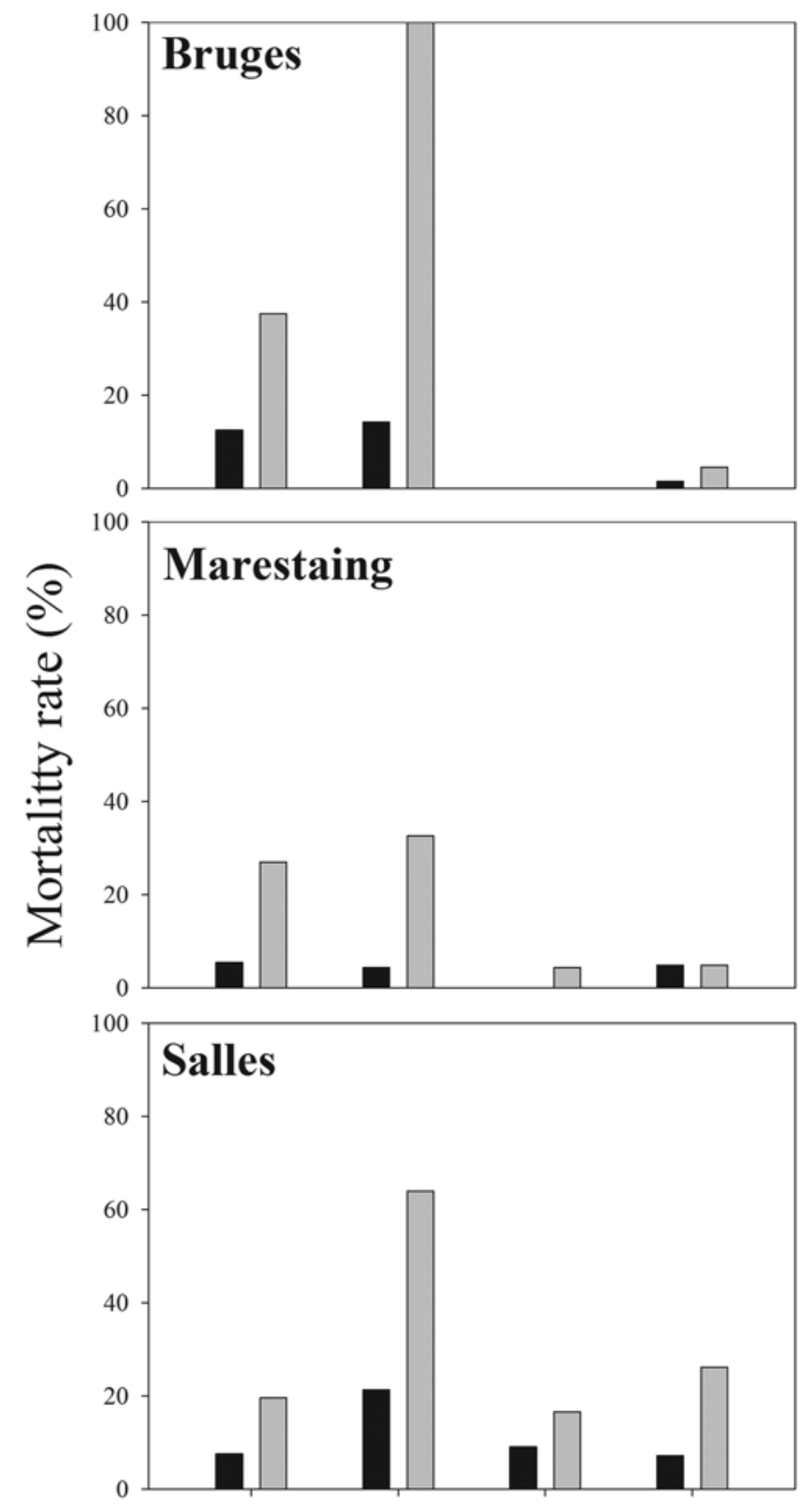

Low cutting Girdling High cutting Juglone

\section{Treatments}

Figure 3. Mortality rate (\%) of Acer negundo individuals per treatment method and experimental site after one $(\mathrm{Y}+1$, black bars) and two $(\mathrm{Y}+2$, grey bars) years of experiment.

During the first year following treatment application, resprouts were significantly affected by the treatments: resprouts were more numerous on trees treated with the high cutting method, and they were smaller on the girdled trees (Table 3, Table 4). Two years after treatment, the same tendency was observed although non- significant due to large variability among trees $(p=0.05$, Table 3$)$. Juglone application did not result in any reduction in resprouting ability, and resprouts were overall as numerous or large than those observed on trees from low and high cutting methods (Table 4).

\section{Discussion}

\section{An Ecologically-friendly Method to Kill the Invasive A. negundo}

Tree girdling proved to be the most efficient method to kill individuals of $A$. negundo within invaded habitats and thus facilitate restoration process. Cutting methods currently used by managers proved to be the less efficient. Girdling has already proven to be efficient in killing individual resprouting trees (Negreros-Castillo and Hall 1994, Loh and Daehler 2007) but its efficiency was species-dependent. It had relatively low efficiency on $R$. pseudoacacia and A. altissima (Kowarik and Säumel 2007, Cierjacks et al. 2013), but was highly successful on Falcataria moluccana (Moluccan albizia) which reached death six to twelve months after girdling (Hughes et al. 2011). In our experiment, the high mortality of girdled $A$. negundo trees did not depend on tree size but instead could be due to the general character of this species that has a small root/shoot ratio (Porté et al. 2011). This could reflect little below-ground reserves and explain the efficiency of girdling in exhausting the tree to death. The major cause of girdled A. negundo survival was related to the healing that could occur after girdling (Figure $2 \mathrm{~B}$ ); this process probably reconstructed the phloem continuum from leaves to roots and compromised the exhaustion of the underground reserves. Healing was greatest on the Marestaing site, which could explain the between-site variability of treatment efficiency. The third year follow-up assessment of mortality by girdling on A. negundo indeed confirmed that a longer repeated treatment reduced the between-site variability. Although the removal of trees by girdling takes time and requires several applications, girdling avoids chemical pollution in natural areas (Noel 1970, Negreros-Castillo and Hall 1994) and should therefore be favored in wetlands. Moreover, dead standing trees can afterwards promote biodiversity by providing shelter or food (Müller and Bütler 2010).

Juglone application did not lead to significant results in our study contrary to previous tests on herbaceous plants or young seedlings (Rietveld 1983, Jose and Gillespie 1998, Ercisli et al. 2005, Tomilov et al. 2006, Terzi 2008). For example, Juglone has been found to limit germination and growth of Alnus glutinosa (black alder) seedlings (Neave and Dawson 1989). Adult trees such as the ones treated here were probably less sensitive than young seedlings. Moreover, we tested crushed walnut leaves opposite to the pure juglone extract used in the aforementioned studies. Further tests using other substances with higher allelopathic power (e.g., ailanthone) as potential inhibitors of A. negundo development could still be conducted. 
Table 4. Mean values $( \pm S E$ ) of the number of resprouts per treated individual and of the diameter of the five biggest resprouts for each of the four control methods tested on Acer negundo adults and saplings. Analyses were performed independently for both monitoring years that followed method application $(Y+1, Y+2)$. Means with the same letter are not considered statistically different $(p>0.05)$.

\begin{tabular}{lccccc}
\hline & & \multicolumn{4}{c}{ Control methods } \\
\cline { 2 - 6 } & Year & Girdling & Low cutting & High cutting & Cutting + Juglone \\
\hline Number of resprouts & $\mathrm{Y}+1$ & $26.3 \pm 6.2 \mathrm{~A}$ & $9.2 \pm 6.0 \mathrm{~A}$ & $30.5 \pm 6.0 \mathrm{~B}$ & $14.7 \pm 6.0 \mathrm{~A}$ \\
& $\mathrm{Y}+2$ & $27.6 \pm 11.3 \mathrm{a}$ & $14.9 \pm 9.4 \mathrm{a}$ & $47.9 \pm 9.4 \mathrm{a}$ & $23.5 \pm 9.3 \mathrm{a}$ \\
Mean diameter $(\mathrm{mm})$ & $\mathrm{Y}+1$ & $4.7 \pm 2.2 \mathrm{~A}$ & $9.2 \pm 2.2 \mathrm{~B}$ & $13.1 \pm 2.1 \mathrm{~B}$ & $11.2 \pm 2.1 \mathrm{~B}$ \\
& $\mathrm{Y}+2$ & $4.1 \pm 1.3 \mathrm{a}$ & $5.8 \pm 1.1 \mathrm{a}$ & $9.5 \pm 1.1 \mathrm{a}$ & $7.6 \pm 1.1 \mathrm{a}$ \\
\hline
\end{tabular}

\section{Management Implications}

Girdling is an efficient eco-friendly control method to achieve local removal of $A$. negundo, a resprouting tree invading European riparian forests and wetlands. Although this control method has been demonstrated in wet and nutrient-rich ecosystems, it can be applied on A. negundo invading dry and resource-poor environments corresponding to its secondary invasive habitats (Erfmeier et al. 2011). When healing development is observed, it only requires repeated girdling for a few years to lead to exhaustion of $A$. negundo below-ground systems and to tree death. Whereas girdling is efficient on A. negundo, partial or total girdling resulted in the spread of $A$. altissima invasions by inducing root-sucker production (Kowarik and Säumel 2007). Thus any transfer to another species should be tested prior to its use as a restoration practice.

To impede the development of $A$. negundo saplings and understory trees into dominant trees of the upper layer of the riparian forest and avoid the formation of mono-specific maple stands, we recommend to particularly consider the timing of canopy opening. Acer negundo presents high growth plasticity in response to increasing light under nutrient-rich conditions, which allows it to outcompete co-occurring native tree species (Porté et al. 2011). Girdling treatment should be applied three years before any cutting of native species (e.g., Populus nigra for pulp or S. alba for fuel biomass) to prevent the expression of A. negundo plasticity. Similarly, girdling should be applied in emergencies after a natural disturbance (wind, storm, flooding) resulting in large canopy openings to limit its competition over local species.

Apart from removing adult trees, land managers should also consider the temporal dynamics and potential reestablishment through seeds (Simberloff 2009). We therefore suggest adapting South Africa's management recommendations for restoring riparian ecosystems (Holmes et al. 2008): (i) minimizing regeneration of $A$. negundo by removing all seedlings and juvenile individuals during two years (optimum seed life span, Möllerová 2005) after the removal of adult trees; and (ii) facilitating the restoration of native tree species using artificial seed-rains.

In 2013 and 2014, this protocol was successfully performed on A. negundo stands by local managers along the
Charente River in France (S. Fonteny, Conseil Général de Charente-Maritime, pers. comm.) inducing 75\% mortality after two years thus avoiding establishment of large invasive populations. Our findings proved that girdling is an efficient eco-friendly method for land managers to achieve local removal of $A$. negundo, a resprouting tree invading riparian forests and wetlands across Europe. Precautions should however be considered when applying this method: (i) treatment needs to be repeated several years until exhaustion and death of $A$. negundo individuals when healing development is observed; (ii) an appropriate timing relatively to canopy opening must be considered for treatment application to avoid the plastic response of A. negundo to light availability and to limit its competitive advantage; and (iii) the removal of seedlings is advised during at least two years to control propagule pressure and to allow native vegetation to recover.

\section{Acknowledgements}

The authors would like to thank technicians and students from University of Bordeaux, INRA Bordeaux, Parc Naturel Régional des Landes de Gascogne, Réserve Naturelle des Marais de Bruges, Syndicat Intercommunal de Gestion et de Valorisation de la Save Gersoise who participated in the field work: S. Brogniez, Y. Ducournau, S. Buyle, L. Degrave, J. Roudie, O. Felis, A. Moreau, P. Vernin, and Y. Guengant. Authors would like to thank Maximilien Larter for English editing. The experiment was funded thanks to the Conseil général du Gers and Conseil général de la Gironde. This study has been carried out with financial support from the French National Research Agency (ANR) in the frame of the Investments for the future Program (ANR-10-IDEX-03-02).

\section{References}

Becker, E., S.F. Shamoun and W.E. Hintz. 2005. Efficacy and environmental fate of Chondrostereum purpureum used as a biological control for red alder (Alnus rubra). Biological Control 33:269-277.

Bottollier-Curtet, M., J-Y. Charcosset, F. Poly, A-M. Planty-Tabacchi and E. Tabacchi. 2012. Light interception principally drives the understory response to boxelder invasion in riparian forests. Biological Invasions 14:1445-1458.

Burch, P.L. and S.M. Zedaker. 2003. Removing the invasive tree Ailanthus altissima and restoring natural cover. Journal of Arboriculture 29:18-24. 
Cierjacks, A., I. Kowarik, J. Joshi, S. Hempel, M. Ristow, M. von der Lippe and E. Weber. 2013. Biological Flora of the British Isles: Robinia pseudoacacia. Journal of Ecology 101:1623-1640.

Correll, D.L. 1996. Buffer Zones and water quality protection: general principles. Pages 7-20 in N. Haycock, T. Burt, K. Goulding and G. Pinay (eds.) Buffer Zones: Their Processes and Potential in Water Protection. The Proceedings of the International Conference on Buffer Zones. Quest Environmental, Harpenden, Hertfordshire, UK.

Delivering Alien Invasive Species Inventories for Europe (DAISIE). 2010. European invasive alien species gateway. www.europealiens.org.

De Jong, M.D. 2000. The BioChon story: Deployment of Chondrostereum purpureum to suppress stump sprouting in hardwoods. Mycologist 14:58-62.

Ding, J.Q., Y. Wu, H. Zheng, W. Fu, R. Reardon and M. Liu. 2006. Assessing potential biological control of the invasive plant, treeof-heaven, Ailanthus altissima. Biocontrol Science and Technology 16:547-566.

Ercisli, S., A. Esitken, C. Turkkal and E. Orhan. 2005. The allelopathic effects of juglone and walnut leaf extracts on yield, growth, chemical and PNE compositions of strawberry cv. Fern. Plant, Soil and Environment 51:283-287.

Erfmeier, A., M. Böhnke and H. Bruelheide. 2011. Secondary invasion of Acer negundo: The role of phenotypic responses versus local adaptation. Biological Invasions 13:1599-1614.

Holmes, P.M., K.J. Esler, D.M. Richardson and E.T.F. Witkowski. 2008. Guidelines for improved management of riparian zones invaded by alien plants in South Africa. South African Journal of Botany 74:538-552.

Holt, J. 2009. Management of invasive terrestrial plants. Pages $126-$ 140 in M.N. Clout and P.A. Williams (eds.) Invasive Species Management: A Handbook of Principles and Techniques. New York, NY: Oxford University Press.

Hood, W.G. and R.J. Naiman. 2000. Vulnerability of riparian zones to invasion by exotic vascular plants. Plant Ecology 148:105-114.

Hughes, R.F., M.T. Johnson and A. Uowolo. 2011. The invasive alien tree Falcataria moluccana: its impacts and management. Pages 218-223 in Y. Wu, T. Johnson, S. Sing, S. Raghu, G. Wheeler, P. Pratt, K. Warner, T. Center, J. Goolsby and R. Reardon (eds.) Proceedings of the XIII International Symposium on Biological Control of Weeds. U.S. Department of Agriculture, Forest Service, Forest Health Technology Enterprise Team, 2012-07.

Itou, T., K. Hayama, A. Sakai, H. Tanouchi, S. Okuda, H. Kushima and T. Kajimoto. 2015. Developing an effective glyphosate application technique to control Bischofia javanica Blume, an invasive alien tree species in the Ogasawara Islands. Journal of Forest Research 20:248-253.

Jose, S. and A.R. Gillespie. 1998. Allelopathy in black walnut (Juglans nigra L.) alley cropping. II. Effects of juglone on hydroponically grown corn (Zea mays L.) and soybean (Glycine max L. Merr.) growth and physiology. Plant and Soil 203:199-205.

Journal Officiel de la République Française. 2006. Arrêté du 12 septembre 2006 relatif à la mise sur le marché et à l'utilisation des produits visés à l'article L. 253-1 du code rural et de la pêche.

Kiernan, K., J. Tao and P. Gibbs. 2012. Tips and strategies for mixed modeling with SAS/STAT Procedures. (Paper 332-2012). In SAS Global Forum.

Kowarik, I. 2003. Biologische Invasionen-Neophyten und Neozoen in Mitteleuropa. Stuttgart, Germany: Eugen Ulmar Verlag.
Kowarik, I. and I. Säumel. 2007. Biological flora of Central Europe: Ailanthus altissima (Mill.) Swingle. Perspectives in Plant Ecology, Evolution and Systematics 8:207-237.

Lamarque, L.J., S. Delzon, M.H. Sloan and C.J. Lortie. 2012. Biogeographical contrasts to assess local and regional patterns of invasion: A case study with two reciprocally introduced exotic maple trees. Ecography 35:803-810.

Loh, R.K. and C.C. Daehler. 2007. Influence of invasive tree kill rates on native and invasive plant establishment in a Hawaiian forest. Restoration Ecology 15:199-211.

Macías, F., J. Molinillo, R. Varela and J. Galindo. 2007. Allelopathy-A natural alternative for weed control. Pest Management Science 63:327-348.

MacKinney, A.L. and C.F. Korstian. 1932. Felling, Girdling, and Poisoning Undesirable Trees in Forest Stands. Journal of Forestry 30:169-177.

Medrzycki, P. 2011. NOBANIS-Invasive alien species fact sheetAcer negundo. Online Database of the European Network on Invasive Alien Species-NOBANIS. www.nobanis.org/ globalassets/speciesinfo/a/acer-negundo/acer_negundo.pdf.

Meloche, C. and S.D. Murphy. 2006. Managing tree-of-heaven (Ailanthus altissima) in parks and protected areas: A case study of Rondeau Provincial Park (Ontario, Canada). Environmental Management 37:764-772.

Möllerová, J. 2005. Notes on invasive and expansive trees and shrubs. Journal of Forest Science 51:19-23.

Müller, J and R. Bütler. 2010. A review of habitat thresholds for dead wood: A baseline for management recommendations in European forests. European Journal of Forest Research 129:981-992.

Neave, I.A. and J.O. Dawson. 1989. Juglone reduces growth, nitrogenase activity, and root respiration of actinorhizal black alder seedlings. Journal of Chemical Ecology 15:1823-1836.

Negreros-Castillo, P. and R.B. Hall. 1994. Four methods for partial overstory removal in tropical forests in Mexico. Journal of Environmental Management 41:237-243.

Noel, A.R.A. 1970. The girdled tree. The Botanical Review 36:162-195.

Patch, N.L., D. Geesing and P. Felker. 1998. Suppression of resprouting in pruned mesquite (Prosopis glandulosa var glandulosa) saplings with chemical or physical barrier treatments. Forest Ecology and Management 112:23-29.

Pimentel, D., R. Zuniga and D. Morrison. 2005. Update on the environmental and economic costs associated with alien-invasive species in the United States. Ecological Economics 52:273-288.

Porté, A.J., L.J. Lamarque, C.J. Lortie, R. Michalet and S. Delzon. 2011. Invasive Acer negundo outperforms native species in nonlimiting resource environments due to its higher phenotypic plasticity. BMC Ecology 11:28.

Rietveld, W.J. 1983. Allelopathic effects of juglone on germination and growth of several herbaceous and woody species. Journal of Chemical Ecology 9:295-308.

Sabo, A. 2000. Robinia pseudoacacia invasions and control in North America and Europe. Restoration and Reclamation Review 6:1-9.

Saccone, P., J-P. Pagès, J. Girel, J-J. Brun and R. Michalet. 2010. Acer negundo invasion along a successional gradient: Early direct facilitation by native pioneers and late indirect facilitation by conspecifics. The New Phytologist 187:831-842.

Säumel, I. and I. Kowarik. 2010. Urban rivers as dispersal corridors for primarily wind-dispersed invasive tree species. Landscape and Urban Planning 94:244-249.

Schopmeyer, C. 1974. Seeds of Woody Plants in the United States. Agriculture Handbook, United State Department of Agriculture, Forest Service, Government Printing Office, Washington, DC. 
Simberloff, D. and P. Stiling. 1996. Risks of species introduced for biological control. Biological Conservation 78:185-192.

Simberloff, D. 2009. The role of propagule pressure in biological invasions. Annual Review of Ecology, Evolution, and Systematics 40:81-102.

Tanaka, N., K. Fukasawa, K. Otsu, E. Noguchi and F. Koike. 2010. Eradication of the invasive tree species Bischofia javanica and restoration of native forests on the Ogasawara Islands. Pages 167-171 in I. Okochi and K. Kawakami (eds.) Restoring the Oceanic Island Ecosystem: Impact and Management of Invasive Alien Species in the Bonin Islands. Tokyo, Japan: Springer.

Terzi, I. 2008. Allelopathic effects of juglone and decomposed walnut leaf juice on muskmelon and cucumber seed germination and seedling growth. African Journal of Biotechnology 7:1870-1874.

Tomilov, A., N. Tomilova, D.H. Shin, D. Jamison, M. Torres, R. Reagan, H. McGray, T. Horning, R. Truong, A. Nava, A. Nava and J.I. Yoder. 2006. Chemical signaling between plants. Pages 55-69 in M. Dicke and W. Takken (eds.) Chemical Ecology: From Gene to Ecosystem. The Netherlands: Springer.

van Wilgen, B., D. Richardson and S. Higgins. 2001. Integrated control of invasive alien plants in terrestrial ecosystems. Land Use and Water Resources Research 1:1-6.

Vilà, M, J.L. Espinar, M. Hejda, P.E. Hulme, V. Jarošík, J.L. Maron, J. Pergl, U. Schaffner, Y. Sun and P. Pyšek. 2011. Ecological impacts of invasive alien plants: A meta-analysis of their effects on species, communities and ecosystems. Ecology Letters 14: 702-708.
Walter, W., H.E. Garrett and L.D. Godsey. 2004. Use of herbicide to reduce stump-sprouting following thinning of an eastern black walnut agroforestry planting. Pages 106-109 in C.H. Michler, P.M. Pijut, J.W. Van Sambeek, M.V. Coggeshall, J. Seifert, K. Woeste, R. Overton and F. Ponder (eds.), Proceedings of the 6th Walnut Council Research Symposium. General Technical Report. NC-243. St. Paul, MN: U.S. Department of Agriculture, Forest Service, North Central Research Station.

Nastasia R. Merceron (corresponding author) BIOGECO, INRA, Univ. Bordeaux, 33615 Pessac, France, nastasia.merceron@u-bordeaux.fr.

Laurent J. Lamarque, BIOGECO, INRA, Univ. Bordeaux, 33615 Pessac, France.

Sylvain Delzon, BIOGECO, INRA, Univ. Bordeaux, 33615 Pessac, France.

Annabel J. Porté, BIOGECO, INRA, Univ. Bordeaux, 33615 Pessac, France. annabel.porte@pierroton.inra.fr.

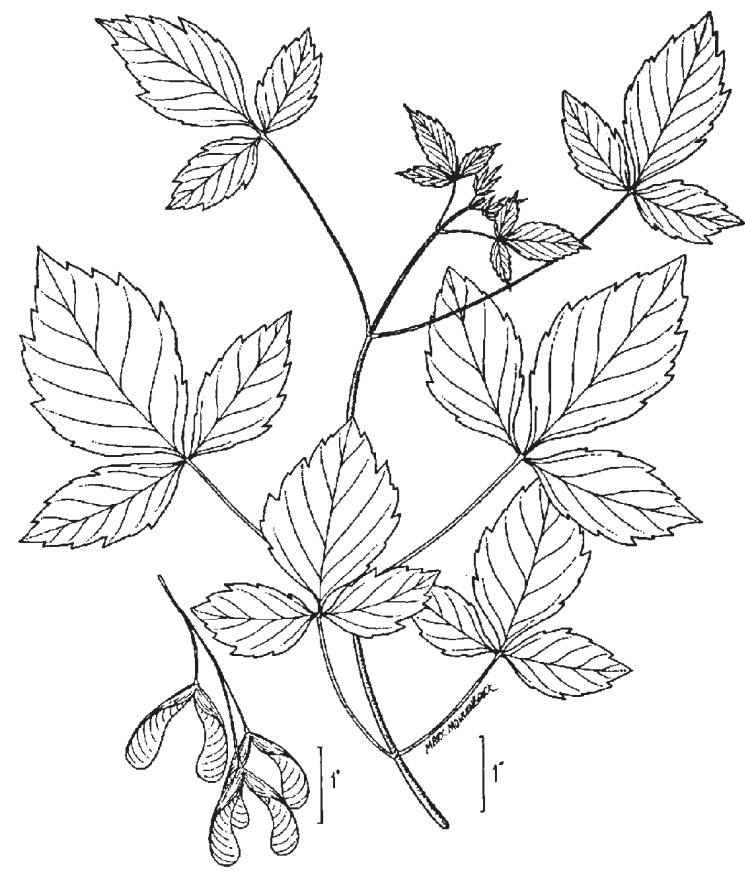

Acer negundo. USDA-NRCS PLANTS Database. USDA NRCS. Wetland flora: Field office illustrated guide to plant species. USDA Natural Resources Conservation Service. 